\title{
Penghapusan Kolom Agama Dalam Kartu Tanda Penduduk*
}

(ELIMINATION OF RELIGION COLUMN IN THE IDENTITY CARD)

\author{
Novita Akria Putri \\ Legal Officer Bank Rakyat Indonesia \\ Jl. Jl. Jenderal Sudirman Kav.44-46. Jakarta \\ E-mail: novitaakria@gmail.com
}

\begin{abstract}
Human rights are claims that must be met in order to maintain the existence and human dignity. Right to religious freedom in fact, is a right enshrined directly in the Constitution of Indonesia. The essence of religious freedom is the recognition that every person has the right to believe and to live worship and engage in what is believed to be the call of God demands the truth. Appreciate the identity of a group is very important, inclusion of a religious identity in residence identity cards so that no one group that is forming a new religious sects that would undermine the nation's integration. Therefore, the elimination of religion column in the ID card is not the primary reason for the creation of the concept of equality before the law that became the main feature of a state of law. However, as the concept of justice of John Rawls, that the interests of certain groups are not allowed to undermine the social justice.
\end{abstract}

Keywords: Removal, Religion Column, KTP

\begin{abstract}
Abstrak: Hak asasi manusia adalah klaim yang mesti dipenuhi demi mempertahankan eksistensi dan martabat manusia. Hak kebebasan beragama nyatanya, adalah hak yang diatur secara langsung dalam UUD 1945. Hakikat dengan kebebasan beragama adalah pengakuan bahwa setiap orang berhak meyakini serta untuk hidup beribadat dan berkomunikasi sesuai dengan apa yang diyakini sebagai panggilan tuntutan Tuhan yang mutlak. Menghargai adanya identitas sebuah golongan amatlah penting, pencantuman sebuah identitas agama dalam kartu identitas kependudukan agar tidak ada suatu golongan yang membentuk suatu sekte-sekte agama baru yang justru akan merusak integrasi bangsa. Oleh karena itu, penghapusan kolom agama dalam KTP tidaklah menjadi alasan utama untuk terciptanya konsep equality before the law yang menjadi ciri utama dari sebuah negara hukum. Namun, sebagaimana konsep keadilan dari Jhon Rawls, bahwa kepentingan golongan tertentu tidaklah diperbolehkan menggerus keadilan sosial.
\end{abstract}

Kata kunci: Penghapusan, Kolom Agama, KTP

* Diterima tanggal naskah diterima: 23 Juli 2015, direvisi: 19 Agustus 2015, disetujui untuk terbit: 22 November 2015. 


\section{Pendahuluan}

Peraturan perundang-undangan akan selalu tertinggal dengan perkembangan yang berjalan lebih cepat. Karena itu ada sebuah pameo yang menyatakan, het recht hinkt achter de feiten aan, artinya hukum dengan terpontang panting mengikuti peristiwanya dari belakang. ${ }^{1}$ Indonesia sebagai Negara hukum sudah sepatutnya mengakomodir hak-hak setiap warga Negara dalam suatu ukuran aturan yang jelas dan memberi kepastian. Ketika suatu Negara hukum amatlah dikaitkan dengan ciri melindungi segenap bangsa Indonesia sebagaimana termaktub dalam UUD NRI 1945 sebagai tujuan nasional bangsa. Nyatanya, perlindungan tersebut dapat direalisasikan dalam bentuk perlindungan hak asasi manusia. Pasal 27 UUD 1945 yang menjamin adanya konsepsi equality before the law, sehingga tidak ada alasan ketika sekelompok warga Negara yang menginginkan haknya dapat terakomodir, terlebih terkait dengan hak konstitusional.

Gagasan penghapusan kolom agama muncul, dan santer dibicarakan berbagai kalangan, tidak lepas dari pernyataan Menteri Dalam Negeri (Mendagri) akan mengizinkan pengosongan kolom agama pada kartu identitas penduduk yang ditujukan bagi warga Negara penganut aliran kepercayaan yang belum diakomodasi oleh undang-undang. ${ }^{2}$ Namun gagasan tersebut yang awalnya bertujuan untuk mengakomodir hak-hak pemeluk keyakinan mulai menyebar menjadi gagasan penghapusan kolom agama bagi seluruh umat beragama di Indonesia. Indonesia amat jelas, merupakan Negara beragama yang digambarkan dalam sila pertama Pancasila yakni Ketuhanan yang Maha esa, dan ditegaskan pula pada pasal 29 UUD $1945^{3}$ yaitu, Negara berdasarkan Ketuhanan yang maha Esa. Jelaslah, bahwa ketika konstitusi sebagai landasan untuk suatu penyelenggaraan pemerintahan sudah menegaskan bahwa esensi Negara Kesatuan Republik Indonesia adalah

\footnotetext{
${ }^{1}$ Jenedjri M. Gaffar, Hukum Pemilu dalam Yurisprudensi Mahkamah Konstitusi, Konstitusi Press, Jakarta, 2013, h.V.

${ }^{2}$ www.theglobal-review.com-ide penghapusana-kolom-agama-merongrong-pancasiladiunduh pada 10 Mei 2015 pukul 13.39.

${ }^{3}$ Sri Soemantri berpendapat bahwa UUD merupakan hasil perjuangan politik bangsa yang berisi pandangan tokoh-tokoh bangsa dalam bentuk tujuan nasional yang hendak diwujudkan, baik untuk waktu sekarang maupun untuk masa yang akan datang. Hal tersebut menguatkan bahwa doktrin atau pendapat ahli hukum tentang undang-undang dasar akan lebih menguatkan dasar argumentasi. Karena, Doktrin merupakan salah satu sumber hukum yang diakui di Indonesia.
} 
mengakui adanya agama dan merupakan identitas dari setiap warga Negara Indonesia yang tentu amat berimplikasi kepada kehidupan sehari-hari.

Kontroversialnya, gagasan tersebut tidak hanya datang dari ahli hukum, bahkan datang dari tokoh-tokoh agama maupun institusi agama yang ada di Indonesia. Oleh karena itu, artikel ini akan menghantarkan kita pada dinamisnya kontroversial gagasan tersebut dan menemukan formulasi yang tetap memperhatikan segala hak yang terjamin dalam konstitusi.

\section{Urgensi Penghapusan Kolom Agama dalam KTP}

“...Buat saya cinta Tanah Air adalah cinta pada manusia dan kemanusian. Saya tidak mengecualikan siapapun..."

(Mahatma Gandhi).

Peryataan Negarawan asal India ini pula dijadikan kutipan oleh The Founding Father Indonesia Soekarno dalam memperteguh gagasan-gagasannya. Menurut Soekarno hal ini dijadikan dalih oleh Mahatma Gandhi dalam memperstukan pihak Islam, pihak Hindu, Parsi, Jainis, dan Sikhyang jumlahnya lebih dari 300 ribu jiwa - enam kali lipat dari penduduk Indonesia pada waktu itu.

Hak asasi manusia adalah klaim yang mesti dipenuhi demi mempertahankan eksistensi dan martabat manusia. ${ }^{4}$ Hak kebebasan beragama nyatanya, adalah hak yang diatur secara langsung dalam UUD 1945, dimana dalam putusan MK 140/PUU-VII/2009, Frans Magni Suseno memberikan penjabarannya sebagai seorang ahli, bahwa hakikat dengan kebebasan beragama adalah pengakuan bahwa setiap orang berhak meyakini serta untuk hidup beribadat dan berkomunikasi sesuai dengan apa yang diyakini sebagai panggilan tuntutan Tuhan yang mutlak. Tentu berkaitan dengan esensi hak konstitusional warga negara, ${ }^{5}$ karena warga negara merupakan unsur

\footnotetext{
${ }^{4}$ Masdar Farid Mas'udi, Syarah Konstitusi UUD 1945 Dalam Perspektif Islam, Jakarta: Pustaka Alvabet, 2010, h: 140.

${ }_{5}^{5}$ Janedji M. Gaffar, Demokrasi Konstitusional Praktik Ketatanegaraan Indonesia Setelah Perubahan UUD 1945, Jakarta: Konstitusi Press, 2012, h. 190.
} 
konstitutif dari suatu Negara. ${ }^{6}$ Tentu umat beragama di Indonesia adalah mereka yang menginginkan pula hak-hak kehidupan sehari-harinya dapat menggambarkan agama atau kepercayaan yang dipercayainya. Bahkan, mengenai urusan perdata maupun administratif seorang yang memiliki kepercayaan di luar agama resmi yang diakui Indonesia pun bagi mereka ingin menunjukkan identitas dirinya sebagai umat yang memiliki kepercayaan.

Adapun Undang-Undang Nomor 24 Tahun 2013 tentang Administrasi Kependudukan adalah Islam, Kristen, Katolik, Hindu, Budha, dan Khonghucu. Tidak ada klausul yang jelas mengenai kepercayaan itu sendiri sehingga untuk meratakan semua hak dan kewajiban yang akan menjadi akibat hukum pencantuman kolom agama. Dalam kartu identitas penduduk digagas adanya penghapusan kolom agama oleh Kementerian Dalam Negeri Republik Indonesia Kabinet Kerja 2014-2019. Adapun sedikit komparasi kepada negara Perancis yang maju, namun tetap memperhatikan hak kesamaan, agar setiap warga negaranya tetap mendapatkan suatu perlakuan yang sama dari segi kebijakan maupun lainnya. Penghapusan kolom nama dan agama pada kartu identitas penduduknya dalam penerimaan kerja salah satu bukti bahwa tujuan penghapusan tersebut adalah daya untuk lebih memajukan negara Indonesia ke arah yang demokratis.

Atas dasar tersebut terlihatlah, apa yang disampaikan Ki Hajar Dewantara adalah hal yang dapat dikorelasikan, yakni bangsa ini adalah bangsa yang tidak mencampuradukkan antara urusan agama dan urusan negara, namun kedudukan agama adalah sebagai nafas kehidupan bangsa ini. Bahwa penghapusan kolom agama adalah hal yang urgen untuk merealisasikan keadilan sosial bagi seluruh rakyat Indonesia terlebih terkait dengan kebebasan dalam beragama dan meyakini sesuatu sesuai dengan hati nuraninya. Penghapusan kolom agama pun tidak akan menggerus semangat religius yang tertuang dalam Sila Pertama Pancasila yakni Ketuhanan Yang Maha Esa. Karena Penghapusan Kolom Agama dalam KTP adalah bentuk kesamaan hak secara pengenalan administratif bagi setiap warga negara bukan untuk menghapuskan nilai-nilai agama yang tertanam dalam warga negara Indonesia.

${ }^{6}$ Bahwa dilihat dari perspektif teori perjanjian social yang mendasari keberadaan demokrasi modern, maka warga negara yang membentuk negara, dengan melakukan perjanjian social berisi ketentuan yang harus dilakukan dan penyelenggaraannya oleh negara. 


\section{Penghapusan Kolom Agama adalah Kebijakan Inkonstitusional}

Jika kita kembali sejenak pada sejarah bangsa, bahwa pembentukan Negara Kesatuan Republik Indonesia didasari dengan UUD 1945 yang menjadi landasan dasar terselenggaranya kehidupan berbangsa dan bernegara. Dimana perumusan UUD 1945 disusun oleh panitia Sembilan yang mewakili berbagai golongan, dan bukanlah hanya berasal dari satu golongan. Golongan tersebut terdiri dari lima orang golongan kebangsaan dan empat orang dari golongan Islam. ${ }^{7}$ Sehingga, jika disimpulkan negara ini adalah negara yang dirumuskan oleh mereka yang menghargai adanya identitas sebuah golongan dan tentu amatlah penting pencantuman sebuah identitas agama dalam kartu identitas kependudukan agar tidak ada suatu golongan yang membentuk suatu sekte-sekte agama baru yang justru akan merusak integrasi bangsa. Sri Soemantri berpendapat bahwa suatu pembangunan politik janganlah sampai merusak integrasi bangsa, sehingga sudah sepatutnya kita menyadari bahwa penghapusan kolom agama merupakan kebijakan yang bertentangan dengan dasar konstitusi Indonesia.

Adapun menurut negara ini memanglah bukan suatu negara agama, namun sebuah simbol keagamaan yang bersifat universal adalah suatu hal yang patut diakomodir melalui pengenalan diri, agar setiap tindakan pemerintah melalui kebijakannya terukur dengan suatu kepastian.

\section{Penghapusan Kolom Agama Menambah Sekat Birokrasi Keperdataan}

Sebagaimana yang dikatakan Satjipto Rahardjo bahwa "hukum adalah instrumentasi dari putusan atau keinginan politik sehingga pembuatan peraturan perundang-undangan sarat dengan kepentingan-kepentingan tertentu." Ketika doktrin tersebut dijadikan dasar selanjutnya maka jelaslah bahwa kebijakan tersebut adalah hasil keberpengaruhan golongan-golongan tertentu tanpa melihat dan menjadikan referensi bahwa toleransi dan kehidupan beragama yang dibangun selama ini adalah kehidupan yang tenteram. Dengan diberikannya hak bagi pemeluk kepercayaan untuk mengosongkan kolom agamanya dalam identitas kependudukannya adalah merupakan hal yang tepat. Bahwa hak golongan tertentu tidak harus

7 Naskah Komprehensif Perubahan Undang-Undang Dasar Negara Republik Indonesia Tahun 1945 Buku II Sendi-Sendi/Fundamen Negara, Mahkamah Konstitusi RI, 2008, h: 8. 
menggerus hak golongan lain yang secara keseluruhan telah mendapatkan kepastian hukum.

Adapun hal-hal yang terkait dengan bidang keperdataan akan lebih sulit birokrasinya ketika dilakukan suatu penghapusan kolom agama yakni :

Pertama; "Setiap pernikahan harus sesuai dengan tata cara agamanya masing-masing." 8 Undang-undang tentang pernikahan ini memberikan kejelasan bahwa kolom agama sangat penting tertera pada kartu tanda penduduk warga negara Indonesia, hal ini untuk mengetahui bagaimana sebuah akad dalam pernikahan itu dilaksanakan dan catatan untuk pengurus adminstrasi pernikahan sangat dibutuhkan untuk memudahkan kinerja dan mengefektifkan waktu.

Kedua; "Hak waris setiap anak dibagi sesuai agamanya masingmasing ataupun keperdataan." Begitu juga dengan hukum waris yang menegaskan bahwa pembagian harta warisan dikembalikan pada agamanya masing-masing, sehingga adanya kolom agama menjadi hal terpenting pada sebuah kartu tanda penduduk warga Indonesia untuk mengetahui bahwa setiap ahli waris akan mendapatkan pembagian harta warisan sesuai agama pewaris.

Selain itu tempat kematian abadi juga menjadi hal yang berpatok pada agama yang dianut oleh seseorang, jika seseorang meninggal bukan pada wilayahnya maka akan dengan mudah orang disekelilingnya untuk mensemayamkannya orang tersebut hanya dengan melihat kolom agama pada KTP-nya dan akan kesulitan jika kolom agama dihilangkan, tak ada identitas lebih jelas untuk mengetahui seseorang dalam memperlakukan sesuai apa yang diyakininya.

\section{Penutup}

Setiap orang wajib menghormati hak asasi manusia orang lain dalam tertib kehidupan bermasyarakat, berbangsa, dan bernegara". 9 Sehingga kerukunan, keadilan, dan kesejahteraan bersama adalah tolak ukur bagi kedamaian suatu negara. Dalam hal ini, undang-undang administrasi kependudukan telah mencoba untuk menyelesaikan masalah yang terjadi,

${ }_{9}^{9}$ Ayat 1 Pasal 28J Undang - Undang dasar Negara Republik Indonesia 1945 
bahwa bagi pemeluk agama yang tercantum dalam salah satu agama yang enam telah ditetapkan dalam undang-undang diharuskan mencantumkan agama yang dianutnya, dan bagi mereka yang tidak meyakini salah satu agama tersebut maka diperbolehkan untuk mengosongkannya, sehingga hak masing-masing warga negara dapat dipenuhi secara bebas dan tidak dipaksakan. Oleh karena itu, setidaknya penghapusan kolom agama dalam KTP tidaklah menjadi alasan utama untuk terciptanya konsep equality before the law yang menjadi ciri utama dari sebuah negara hukum. Namun, sebagaimana konsep keadilan dari Jhon Rawls, bahwa kepentingan golongan tertentu tidaklah diperbolehkan menggerus keadilan sosial.

\section{Pustaka Acuan}

Gaffar, Janedjri M, Demokrasi Konstitusional Praktik Ketatanegaraan Indonesia Setelah Perubahan UUD 1945. Jakarta: Konstitusi Press, 2012 Hukum Pemilu dalam Yurisprudensi Mahkamah Konstitusi, Konstitusi Press. Jakarta.

Mas'udi, Masdar Farid, Syarah Konstitusi UUD 1945 Dalam Perspektif Islam. Jakarta: Pustaka Alvabet, 2010

Naskah Komprehensif Perubahan Undang-Undang Dasar Negara Republik Indonesia Tahun 1945

Buku II Sendi-Sendi/Fundamen Negara, Mahkamah Konstitusi RI, 2008 www.theglobal-review.com-idepenghapusana-kolom-agama-merongrongpancasila- diunduh pada 10 Mei 2015 pukul 13.39.

Maggalatung, A Salman. "Hubungan Antara Fakta, Norma, Moral, Dan Doktrin Hukum Dalam Pertimbangan Putusan Hakim" Jurnal Cita Hukum [Online], Volume 2 Number 2 (1 December 2014). doi:10.15408/jch.v1i2.1462

Rohim, Nur. "Kontroversi Pembentukan Perppu No. 1 Tahun 2013 Tentang Mahkamah Konstitusi Dalam Ranah Kegentingan Yang Memaksa" Jurnal Cita Hukum [Online], Volume 2 Number 1 (1 June 2014). doi:10.15408/jch.v1i1.1454 
Yunus, Nur Rohim, Restorasi Budaya Hukum Masyarakat Indonesia, Bogor: Jurisprudence Press, 2012.

\section{Peraturan Perundang-undangan}

Undang-Undang : Undang-Undang Dasar NRI 1945

Undang-Undang Nomor 24 Tahun 2013 tentang Administrasi Kependudukan 